Beata Jezierska

Uniwersytet im. Adama Mickiewicza w Poznaniu

\title{
Problem frazeologizmów w przekładzie literackim francusko-polskim (na wybranych przykładach)
}

Niniejszy artykuł ma charakter prezentacji małej części wyników badań, których celem było przyjrzenie się funkcjonowaniu kanonicznych postaci frazeologizmów i użyć innowacyjnych we współczesnych tekstach prozatorskich będących tłumaczeniami z języka francuskiego na język polski oraz próba uporządkowania i nazwania relacji przekładowych zachodzących pomiędzy użytymi w tłumaczeniach frazeologizmami a ich oryginalnymi kontekstami. Wspomniane badania nie powielają klasycznego już w literaturze językoznawczej pomysłu opisywania mechanizmów czy sposobów przekładu frazeologizmów ${ }^{1}$, tzn. szukania odpowiedzi na pytanie, w jaki sposób występujący w tekście źródłowym frazeologizm został potraktowany przez thumacza w procesie tworzenia tekstu docelowego w innym języku. W tym wypadku przedmiotem obserwacji czynię w pierwszym rzędzie kształt językowy polskiego przekładu, skupiając się na użyciach frazeologizmów, a dopiero w dalszej kolejności sięgam do tekstu źródłowego i próbuję zestawione porównawczo przykłady na tej podstawie klasyfikować. Nie zawsze bowiem w tych miejscach, w których thumacz zdecydował się na użycie frazeologizmu, w tekście wyjściowym występuje analogiczna jednostka językowa.

${ }^{1}$ Na podstawie materiału słowacko-polskiego i polsko-słowackiego bardzo rzetelnie przeprowadziła to Bożena Rejakowa. Problematyce tej poświęciła kilka swoich prac, w tym książkę Mechanizmy językowe w przekładzie związów frazeologicznych na materiale języka polskiego i słowackiego, Lublin 1994. Jeśli zaś chodzi o prace porównawcze polsko-czeskie, to trzeba wspomnieć tu o artykule Mieczysława Basaja Ekwiwalencja ttumaczeń frazeologizmów (na przykładzie języka czeskiego i polskiego), w: Z problemów frazeologii polskiej i stowiańskiej, pod red. M. Basaja i D. Rytel, t. 1, Wrocław 1982, s. 157-165. 
Do szczegółowych analiz wybrałam szesnaście ostatnich polskich przekładów powieści wyróżnionych Nagrodą Goncourtów (fr. Prix Goncourt) ${ }^{2}$, należącą z pewnością do grupy najbardziej prestiżowych krajowych nagród literackich za dzieła francuskojęzyczne. Ta - przyznawana co roku na początku listopada na podstawie werdyktu dziesięcioosobowego jury, w którego skład wchodzą wybitni francuscy literaci - w zdecydowanie największym stopniu wpływa na poczytność danego tytułu i, tym samym, wzrost liczby sprzedanych egzemplarzy. Jest więc bezdyskusyjnie znacząca i tylko dodatkowo potwierdza fakt, iż mamy tu do czynienia z dziełami najwyższej literackiej próby. Dla thumacza tekst tego rodzaju z pewnością stanowi wyzwanie szczególne: zadanie pasjonujące i trudne lub - pasjonujące, bo trudne. Frazeologizmy zaś stanowią w tym kontekście chyba jedną z najbardziej skomplikowanych materii.

Ze względu na obszerność korpusu, na który składa się blisko 4000 jednostek wraz z wynotowanymi przeze mnie cytatami, nie jestem w stanie omówić wszystkich aspektów problemu frazeologizmów w przekładzie, dlatego też skupię się na szczegółowym zaprezentowaniu kilkunastu zaledwie wybranych przykładów. Poniższe omówienie niech więc będzie jedynie próbką opracowania zebranego materiału. Na podstawie zestawienia cytatów z polskich przekładów oraz - porównawczo - francuskich tekstów wyjściowych zbudowałam bazę danych umożliwiającą analizę związków zachodzących pomiędzy zastosowanymi przez polskiego tłumacza frazeologizmami a oryginalnymi kontekstami. Nazywam je relacjami przekładowymi i - w dalszej kolejności tworzę ich umowną klasyfikację, choć - jak pokazuje praktyka i jak łatwo można się domyślić - nie jest ona wyczerpująca, ponieważ niektórych sytuacji

${ }^{2}$ Są to odpowiednio (w nawiasie podaję rok wydania francuskiego, który najczęściej pokrywa się z datą przyznania nagrody): M. Houellebecq, Mapa i terytorium, przeł. B. Geppert, Warszawa 2011 (2010); M. NDiaye, Trzy silne kobiety, przeł. K. Sławińska, Katowice 2010 (2009); A. Rahimi, Kamień cierpliwości, przeł. M. Kamińska-Maurugeon, Kraków 2009 (2008); G. Leroy, Alabama song, przeł. W. Gilewski, Warszawa 2009 (2007); J. Littell, Łaskawe, przeł. M. Kamińska-Maurugeon, Kraków 2008 (2006); L. Gaudé, Stońce Scortów, przeł. J. Giszczak, Warszawa 2005 (2004); J.P. Amette, Kochanka Brechta, przeł. A. Węgrzyn, Warszawa 2004 (2003); P. Quignard, Btędne cienie, przeł. T. Komendant, Warszawa 2004 (2002); J. Echenoz, Odchodze, przeł. J. Polachowska, Warszawa 2008 (1999); A. Makine, Francuski testament, przeł. M. Hołyńska, Warszawa 1997 (1995); D. Van Cauwelaert, Bilet w jedna stronę, przeł. H. Karpińska, Warszawa 1999 (1994); A. Maalouf, Skała Taniosa, przeł. D. Ben Ghorbal, Warszawa 1998 (1993); J. Rouaud, Pola chwaty, przeł. E. Wende, Warszawa 1996 (1990); M. Duras, Kochanek, przeł. L. Kałuska, Kraków 1989 (1984); P. Modiano, Ulica ciemnych sklepików, przeł. E. Bąkowska, Warszawa 1981 (1978); R. Gary, Życie przed soba, przeł. M. Braunstein, A. Daniłowicz, Warszawa 1978 (1975). Na wydania polskie nieraz czekaliśmy kilka lat, a - jak widać na podstawie niniejszego zestawienia (w którym mamy do czynienia z dużą luką czasową choćby między rokiem 1984 a 1990) - niektóre dotąd nie zostały przetłumaczone na język polski. 
nie da się jednoznacznie zinterpretować i przyporządkować do grupy zabiegów analogicznych czy nawet podobnych. Tymi właśnie wypadkami pośrednimi bądź granicznymi chciałabym zająć się tutaj w szczególności.

Najpierw przedstawię krótko projekt klasyfikacji przeanalizowanych przeze mnie w tysiącach kontekstów relacji przekładowych. Wyróżniam w ten sposób pięć ich głównych typów, wyłączając na razie sygnalizowane wcześniej sytuacje z pogranicza, tzn. niemożliwe do jednoznacznego przyporządkowania bądź odosobnione, jednorazowe, nieporównywalne.

\section{Ekwiwalent strukturalno-semantyczny}

Pierwszy typ obejmuje sytuacje, w których użyty w polskim przekładzie związek frazeologiczny znajduje pełne odzwierciedlenie w postaci frazeologizmu występującego w tekście oryginalnym, tj. - lepiej - stanowi konsekwencję obecności takiej akurat jednostki w kontekście francuskim, przy czym obie są ekwiwalentne zarówno na poziomie znaczenia, jak i struktury gramatycznej (przy uwzględnieniu naturalnych różnic pomiędzy oboma systemami językowymi: polskim i francuskim ${ }^{3}$ ). Są to odpowiedniości w rodzaju: tajemnica zawodowa < secret professionel; prawo serii < la loi des séries; manna z nieba < la manne céleste; pod czyjąś nieobecność < en absence de quelqu'un; śledzić katem oka < surveiller du coin de l'oeil; wyobrażać sobie Bóg wie co < s'imaginer Dieu sait quoi ${ }^{4}$. Potwierdzają one - przez swoją liczebność - fakt, że znaczna część zasobów frazeologicznych języków europejskich (a nawet, jak wspomina m.in. Mieczysław Basaj, tych odległych strukturalnie i genetycznie) jest z wielu powodów wspólna, przy czym „najbardziej interesująca jest wspólnota zwyczajów i odzwierciedlających je procesów myślenia, wspólnota form metaforycznych widzenia świata przez

${ }^{3}$ Bardzo ciekawą klasyfikację polskich odpowiedników frazeologizmów francuskich ze względu na ich strukturę formalną, przy ograniczeniu do jednostek mających w składzie czasownik aller 'iść, jechać' jako czasownik ruchu, przedstawiła Joanna Porawska w pracy Semantyczne aspekty frazeologii czasowników ruchu: francuskie zwiąki frazeologiczne zawierające czasownik aller $i$ ich formalno-semantyczne odpowiedniki w języku polskim, Kraków 1991, s. 25-36.

${ }^{4}$ Znaki graficzne użyte w sposób niestandardowy:

$<$ oznacza kierunek tłumaczenia (tworząc rodzaj strzałki),

[ ] w nawiasie kwadratowym podaję tłumaczenia „słowo w słowo” frazeologizmów bądź cytatów (by umożliwić odbiór czytelnikowi niewładającemu językiem francuskim).

Zgodnie $\mathrm{z}$ terminologią przekładową - „tłumaczenie słowo $\mathrm{w}$ słowo - fr. mot à mot - to thumaczenie dosłowne, które polega na przeniesieniu do tekstu docelowego elementów tekstu wyjściowego, bez zmiany ich szyku"; Terminologia tlumaczenia, pod red. J. Delisle'a, H. Lee-Jahnke, M.C. Cormier, przekład i adaptacja T. Tomaszkiewicz, Poznań 2004, s. 107. 
różne narody, w tym także narody niemające ze sobą bezpośrednich kontaktów językowych" ${ }^{5}-n b$. o jej istnieniu był przekonany już uważany za ojca frazeologii Charles Bally, według którego „mentalność europejska [...] jest warunkiem stworzenia języka uniwersalnego, ściślej języka międzynarodowego, dla tych grup, które w owej mentalności uczestniczą"6; to zresztą osobny problem badawczy. Uwaga ta nie będzie dotyczyć przykładów zebranych do niniejszego opracowania, w każdym razie - przy okazji omawiania kwestii internacjonalizmów frazeologicznych - należy zdawać sobie sprawę z tego, że - zacytuję Annę Krzyżanowską - istnieją także ,jednostki podobne pod względem budowy i składu leksykalnego, mające jednak różne znaczenie, np. pol. przenieść się do boskiej chwaly 'umrzeć', franc. partir pour la gloire 'być pijanym', ang. to go to glory 'umrzeć' [...]"?

\section{Ekwiwalent wyłącznie semantyczny}

Do typu drugiego (wraz z pierwszym stanowi on największą część wszystkich realizacji, prawie połowę) zaliczam te $\mathrm{z}$ wyekscerpowanych przykładów, w których frazeologizm zastosowany w polskim tekście został użyty jako następstwo istnienia frazeologizmu w tekście wyjściowym, a relacja pomiędzy nimi jest oparta tylko na odpowiedniości semantycznej, tzn. różni je skład leksykalny (czasem nieznacznie, innym razem w bardzo wysokim stopniu), np. rajskie jabłko < pomme originaire [słowo w słowo: jabłko pierwotne]; styszeć ciagle tę sama śpiewkę < entendre cette rengaine [słyszeć tę śpiewkę]; być przyłapanym na goracym uczynku < être pris sur le fait [być wziętym na czynie]; wszystkie drogi stoja otworem < tous les champs sont ouverts [wszystkie pola są otwarte]; nie ma żartów < ça ne pardonne pas [to nie wybacza]. (Należy zaznaczyć, iż wszystkich powyższych zestawień, zwłaszcza ze względu na naturę badań i ich metody, nie można traktować bezwarunkowo jako ekwiwalentów „obiektywnych”, słownikowych - są to realizacje tekstowe).

${ }^{5}$ M. Basaj, Z problematyki europeizmów frazeologicznych, w: Z problemów frazeologii polskiej i stowiańskiej, pod red. M. Basaja i D. Rytel, t. 2, Wrocław 1985, s. 73.

${ }^{6}$ Stylistyka Bally'ego: wybór tekstów, pod red. M.R. Mayenowej, teksty przeł. i opatrzyła przyp. U. Dąmbska-Prokop, Warszawa 1966, s. 21.

${ }^{7}$ A. Krzyżanowska, Udziat internacjonalizmów we frazeologii francuskiej i polskiej (na podstawie związków oznaczających śmierć), w: Język a kultura, t. 7: Kontakty języka polskiego z innymi językami na tle kontaktów kulturowych, pod red. J. Maćkiewicz i J. Siatkowskiego, Wrocław 1992, s. 132. 


\section{Frazeologiczna półkalka}

Do tej grupy zakwalifikowałam przykłady bardziej skomplikowane, ponieważ chodzi w tym wypadku o takie zastosowanie i przetworzenie polskiego frazeologizmu w przekładzie, które jest wynikiem co najmniej częściowego przekalkowania z oryginalnego francuskiego kontekstu. W rezultacie mamy do czynienia w polskim tekście z różnego typu innowacjami frazeologicznymi, głównie modyfikującymi, inspirowanymi obcymi postaciami analogicznych w danych miejscach tekstu jednostek bądź struktur. Tak się dzieje np. wtedy, gdy dochodzi do wymiany jakiegoś elementu leksykalnego w składzie polskiego frazeologizmu, np. „Pożerał ją oczami, z nadzieją na znak z jej strony, który przerwie ciszę" (Stońce Scortów, 15) ${ }^{8}<$ „Il la mangeait des yeux, à l'affût du moindre signe qui rompe cet état de silence" (Le soleil des Scorta, 19). Powstała w ten sposób na zasadzie metonimii innowacja wymieniająca pożerać kogoś oczami (wobec formy kanonicznej pożerać kogoś wzrokiem) - o ile nie uznać jej za wariant $\mathrm{w}$ ciągu synonimicznym jednostki wielokształtnej ${ }^{9}$ - jest prostą konsekwencją występującego we francuskim tekście wyjściowym ekwiwalentnego strukturalno-semantycznie zwrotu manger qqn. les yeux. Inny mechanizm zadziałał w wypadku innowacji skracającej rwać sobie włosy (z jej formą kanoniczną: rwać sobie wlosy z głowy) wobec francuskiego s'arracher les cheveux w takim oto fragmencie: „Rwała sobie włosy, których i tak nie miała, i z oczu płynęły jej łzy niewdzięczności” (Życie przed sobq, 13) < „Elle s'arrachait les cheveux qu'elle n'avait déjà pas et elle avait des larmes qui coulaient d'ingratitude" (La Vie devant soi, 20). Trudno powiedzieć, dlaczego tłumaczki zdecydowały się na taką modyfikację, z pewnością jednak można stwierdzić, że tym razem jest to wynik tłumaczenia na zasadzie morfem za morfem i niechęci do zastosowania bogatszej o jeden składnik leksykalny polskiej formy frazeologicznego ekwiwalentu. Jeszcze inaczej rzecz wygląda w cytacie: „Widzę, że w tym mieści się wszystko. Jest w tym wszystko i nic jeszcze nie jest grane, widzę to po oczach, wszystko jest w oczach” (Kochanek, 19) < „Je vois bien que tout est là. Tout est là et rien n'est encore joué, je le vois dans les yeux, tout est déjà dans les yeux" (L'amant, 29). Przekalkowana fraza nic nie jest grane stanowi rodzaj nawiązania do utrwalonego w polskiej normie co jest grane 'co się dzieje' ${ }^{10}$.

${ }^{8}$ Każdy cytat pochodzący z materiału badawczego podaję wraz z lokalizacją, wskazując w nawiasie okrągłym tytuł książki i, po przecinku, numer strony.

9 Tak właśnie w Wielkim słowniku frazeologicznym $P W N$ z przysłowiami, pod red. A. Kłosińskiej, E. Sobol i A. Stankiewicz, Warszawa 2005.

${ }^{10}$ Zob. S. Bąba, J. Liberek, Słownik frazeologiczny wspótczesnej polszczyzny, Warszawa 2002. 


\section{Frazeologizm drugiego wyboru}

W tej grupie znalazły się frazeologizmy, które tłumacze umieścili w danych miejscach pomimo istnienia możliwych do zastosowania polskich ekwiwalentów strukturalno-semantycznych bądź ekwiwalentów wyłącznie semantycznych, np. „W czasach swej świetności, gdy jego hultajska sława sięgała zenitu, Luciano Mascalzone często odwiedzał Montepuccio (Stońce Scortów, 18) < „A l'heure de sa gloire, c'est-à-dire à l'apogée de sa carrière de vaurien, Luciano Mascalzone venait fréquemment à Montepuccio" (Le Soleil des Scorta, 19). W tym przykładzie wyrażenie à l'apogée de sa carrière mogłoby zostać przetłumaczone wierniej, również za pomocą związku frazeologicznego, poprzez u szczytu jego kariery - thumacz wolał jednak inne rozwiązanie, które nazwałam frazeologizmem drugiego wyboru. Podobnie postąpiła tłumaczka Biletu w jedna stronę, używając w miejscu francuskiego $j$ 'en avais marre frazeologizmu miałem wszystkiego powyżej uszu, podczas gdy możliwe było przekazanie znaczenia w wyrażeniu miałem tego dość: „Kretyński akcent, z którym ten chłopak posługiwał się moim językiem, niesamowicie mnie wnerwił, i chętnie bym się z nim pobił jak Arab z Arabem, żeby wreszcie z kimś nawiązać prawdziwy kontakt, a w ogóle to miałem wszystkiego powyżej uszu" (Bilet w jedna stronę, 91) < „Et je lui en voulais à celui-là aussi d'avoir cet accent débile pour parler ma langue, je me serrais volontiers battu avec lui entre Arabes pour communiquer normalement avec quelqu'un, pour une fois, comme je savais faire; j'en avais marre, marre, marre" (Un aller simple, 80).

Niekiedy takie tłumaczeniowe odstępstwa od nadrzędnej przekładowej powinności jak najwierniejszego na wszystkich poziomach oddania treści prowadzą do powstawania kontaminacji, niekoniecznie normatywnych, np. „Alkohol spełnił rolę, której nie wziął na siebie Bóg, również tę, żeby mnie zabić, zabić” (Kochanek, 10) < „L'alcool a rempli la fonction que Die n'a pas eue, il a eu aussi celle de me tuer, de tuer" (L'amant, 15). W tekście wyjściowym mamy więc połączenie ,spełnić funkcję" - nie wiadomo dlaczego thumaczka wolała tu „rolę". Użycie to świadczy w każdym razie o nieznajomości normy wzorcowej.

\section{Niezależne użycie frazeologizmu w przekładzie}

Jak się okazuje, stosunkowo częstym zabiegiem jest użycie przez tłumacza frazeologizmu, mimo iż w tekście wyjściowym nie pojawia się żadna jednostka tego rodzaju - tutaj jest konieczne przytoczenie kilku cytatów dla zilustrowania zjawiska (ich wybór w niniejszym artykule, ze względu na ogromną objętość 
materiału, ograniczam losowo): „Często mam przed oczami ten obraz, który ja jedna jeszcze widzę i o którym nigdy nie mówiłam” (Kochanek, 7) < „Je pense souvent à cette image que je suis seule à voir encore et dont je n'ai jamais parlé" (L'amant, 9) [myślę często o tym obrazie, który ja jedna jeszcze widzę i o którym nigdy nie powiedziałam]; ,Starszy pan, skryty, zamknięty w sobie, jakby nieobecny" (Pola chwaty, 7) < „Un vieil homme secret, distant, presque absent” (Les champs d'honneur, 9) [starszy, skryty człowiek, zdystansowany, prawie nieobecny]; „Krzyknęła, że mam fioła, że Jean-Pierre jest chory, że trzeba go odtransportować samolotem sanitarnym do kraju" (Bilet w jedna stronę, 118) < „Elle a crié que j'étais cinglé, que Jean-Pierre était malade, qu'il fallait le rapatrier sanitaire" (Un aller simple, 104) [krzyknęła, że jestem stuknięty, że Jean-Pierre jest chory i trzeba go przetransportować do kraju z przyczyn zdrowotnych]; „Tylko Pepita Bourguignon nie ruszyła palcem” (Mapa i terytorium, 76) $<$,Il y a juste Pépita Bourguignon qui n'a rien fait” (La carte et le territoire, 86) [jest tylko Pepita Bourguignon, która nie zrobiła nic]; „Komu przyszłoby to do głowy?” (Kochanek, 11) < „Qui aurait pu penser à ça ?” (L'amant, 17) [kto mógłby pomyśleć o tym? ${ }^{11}$. Powyżej przytoczyłam przykłady użyć kanonicznych; nie brakuje tu wszakże innowacji frazeologicznych różnego typu, jak np. wyciać komuś bardzo sprytny numer (wobec kanonicznego wyciać komuś numer): „Minę miała chytrą, a nawet zwycięską, jakby wycięła komuś bardzo sprytny numer" (Życie przed soba, 24) < „Elle avait pris un air malin et même vainquer. C'est comme si elle avait fait quelque chose de très astucieux et de très fort" (La Vie devant soi, 38) [zrobiła - dosłownie wzięła - minę chytrą i nawet zwycięską. To tak, jakby zrobiła coś podstępnego i mocnego].

\section{Sytuacje niejednoznaczne}

W tej grupie wyróżniam sytuacje, których nie udało mi się do tej pory jednoznacznie zakwalifikować lub nie istnieją inne przykłady podobnych zabiegów (nie ma więc sensu mówić o osobnym typie relacji przekładowej, bo niepotrzebnie rozbudowałoby to przedstawianą tu próbę klasyfikacji). Pierwszy przykład

${ }^{11} \mathrm{Nb}$. w zebranym materiale frazeologizmy z komponentem głowa są dość częste, a przykład coś przychodzi komuś do głowy dokładnie omówiłam w kontekście porównawczym polsko-francuskim przy okazji referowania problemu budowy artykułu hasłowego w artykule poświęconym makro- i mikrostrukturze Polsko-francuskiego słownika frazeologicznego Leona Zaręby (B. Jezierska, Makro- $i$ mikrostruktura słownika przekładowego w świetle polskiej praktyki frazeograficznej (na podstawie „Polsko-francuskiego stownika frazeologicznego” Leona Zaręby), w: Perspektywy współczesnej frazeologii polskiej. Między teoria a praktyka frazeograficzna, pod red. G. Dziamskiej-Lenart i J. Liberka, Poznań 2013, s. 91-99). 
dotyczy takiego użycia polskiego frazeologizmu, dla którego nie istnieje bezpośrednie uzasadnienie wynikające z obecności w danym miejscu francuskiego ekwiwalentu, lecz w oryginale można wskazać w bliskim kontekście inną jednostkę tego rodzaju, nasuwającą dane frazeologiczne rozwiązanie przekładowe na zasadzie skojarzenia. Może to być jakiś wspólny element leksykalny zawarty w polskim frazeologizmie i innej, pojawiającej się w tym samym zdaniu tekstu wyjściowego, analogicznej jednostce, tak jak to ma miejsce w motcie z Życia przed soba Romaina Gary'ego: „Powiedziałem: «Życie ma smak jedynie dla szaleńców». Mówią: «Oszalałeś przez Tego, którego kochasz». Yafi'i, Raud al rayahin” (Życie przed soba, motto) < „Ils ont dit : «Tu devenu fou à cause de Celui que tu aimes.» J'ai dit : «La saveur de la vie n'est que pour fou.» Yâfi'î, Raoudh al rayâhîn" (La Vie devant soi, motto), co słowo w słowo brzmiałoby: „Powiedzieli: «Stajesz się szalony z powodu Tego, kogo kochasz». Powiedziałem: «Smak życia jest tylko dla szalonego». Yafi'i, Raud al rayahin”. Tłumaczki zdecydowały się więc po pierwsze na zamianę kolejności zdań składowych motta, po drugie użyły innego frazeologizmu (mieć smak) niż ten, który mógłby zostać zastosowany, gdyby próbować ściślej trzymać się tekstu wyjściowego: smak życia < la saveur de la vie.

Użyty w następującym zdaniu frazeologizm przywodzić na myśl: „Imię Wen Bigu przywodzi na myśl imię Laozi: lao (stary) i zi (dziecko)" (Błędne cienie, 8) $<$ „Le nom de Wen Bigu fait penser au nom de Lao-tseu : lao (vieux) et tseu (enfant)" (Les ombres errantes, 14) poświadcza z kolei relację, którą zaobserwowałam również w innych kontekstach, lecz (jak w poprzednio omawianym wypadku) dotąd uważam tę reprezentację za zbyt małą, by rozbudować moją klasyfikację. Chodzi tu w każdym razie o to, że powyższe przywodzić na myśl < faire penser à qqch. [robić, myśleć o czymś], podobnie jak inne zestawienia z polskim frazeologizmem w rodzaju dać spokój < laisser tomber qqch. [pozwolić upaść coś], mają to do siebie, że we francuskim oryginale pojawia się w tym miejscu specyficzna dla tego języka konstrukcja składniowa pozwalająca na seryjne tworzenie wyrażeń o podobnych funkcjach semantyczno-stylistycznych, ale niebędąca jednocześnie frazeologizmem.

W omawianej grupie należałoby umieścić także przypadkowo odnalezione sytuacje, w których doszło do pomyłki przekładowej, może nawet błędu, wynikającego z niezupełnego panowania nad tekstem (lub braku pomysłu na inne rozwiązanie). Są one niemożliwe do wychwycenia bez sięgnięcia do oryginału, jak tutaj: „Objąłem ją za szyję, pocałowałem. Na ulicy mówili o niej, że nikt nie miał do niej serca, i to prawda, nikt się nią nie zajmował" (Życie przed soba, 15) < „Je lui ai mis les bras autour du cou et je l'ai embrasée. On disait dans la rue que c'était une femme sans cœur et c'est vrai qu'il n'y avait personne pour s'en occuper" ( $L a$ Vie devant soi, 23). Ten sam fragment mógłby zostać przetłumaczony zgoła inaczej, 
np.: „Objąłem ją ramionami wokół szyi i przytuliłem (pocałowałem) ${ }^{12}$. Mówiono na ulicy, że była to twarda kobieta - i to prawda, że nie było nikogo, kto by się nią zajmował”. W oryginale pojawia się właśnie „une femme sans cœur”, czyli „twarda kobieta" (ponieważ francuskie sans cœur [bez serca] 'dur' [twardy] $]^{13}$ nie jest całkowicie ekwiwalentne wobec polskiego bez serca), tymczasem thumaczki cały fragment nieco przeinterpretowały i użyły innego frazeologizmu.

\section{Zakończenie}

Celem nadrzędnym, towarzyszącym powyższym rozważaniom nad dwutekstem francusko-polskim lub inaczej - zestawieniem dwu przekazów artystycznych specyficznie od siebie zależnych - w kontekście relacji przekładowej zachodzącej pomiędzy użytym w polskim przekładzie związkiem frazeologicznym a kształtem językowym jego otoczenia oryginalnego, jest próba odpowiedzi na pytanie: dlaczego właśnie w tym miejscu pojawił się związek frazeologiczny i dlaczego ten? Usiłuję zatem odkryć ('odsłonić, co było zakryte') podłoże danego frazeologizmu (występującego w postaci kanonicznej lub w formie innowacji) $\mathrm{w}$ tekście nowym, lecz zależnym od obcojęzycznego oryginału, a także zastanowić się - odwołując się do dotychczasowych ustaleń frazeologicznych i translatologicznych - jakie mechanizmy wpływają na decyzję o jego użyciu; wreszcie - czy można zaobserwować jakieś regularności w tym zakresie. W ten sposób tłumacz staje się - używając określenia Anny Legeżyńskiej - drugim autorem tekstu, gdyż: „Na podstawie lektury jedynie przekładu odbiorca nie jest w stanie określić funkcji i konsekwencji zastosowanych operacji translatorskich"14. A są one - co potwierdza analiza jednego tylko aspektu kształtu językowego przekładu, tj. postaci związków frazeologicznych - wcale nieregularne, nieraz niezależne, wymagające, skomplikowane i wielopoziomowe.

Przyjrzyjmy się jeszcze raz kilku przykładom: „Kawałek rajskiego jabłka utkwił mi w gardle” (Błędne cienie, 6) < „Un morceau de pomme originaire est resté coincé au centre de ma gorge" (Les ombres errantes, 10) - widzimy tu ciekawy zabieg powtórnej metaforyzacji biblizmu, który prowadzi do zamie-

${ }^{12}$ Możliwe są obie interpretacje czasownika embrasser 'przytulać, całować', przy czym znaczenie 'przytulać' jest prymarne, a 'całować' wtórne, ze względu na ewolucję znaczenia czasownika baiser 'całować' (zob. hasło embrasser w: Le Robert pour tous, pod red. D. Morvana, Paris 1998).

13 Zob. ibidem, hasło cœur.

${ }^{14}$ A. Legeżyńska, Tlumacz, czyli „drugi autor”, w: Miejsca wspólne. Szkice o komunikacji literackiej i artystycznej, pod red. E. Balcerzana i S. Wysłouch, Warszawa 1985, s. 178. 
rzonej defrazeologizacji, znajdującej odzwierciedlenie w tekście wyjściowym. Udosłownienie wynikające $\mathrm{z}$ tego rodzaju operacji - tym razem niezwiązanej z występowaniem związku frazeologicznego w tekście wyjściowym - ma miejsce także tutaj: „Widok nieruchomego morza, lśniącego w upale, był wyraźnym dowodem, że droga wiedzie na manowce” (Stońce Scortów, 12) < „L'apparition de cette mer immobile, brillante de chaleur, imposait la certitude que le chemin ne menait nulle part" (Le Soleil des Scorta, 12), ponieważ po francusku po prostu ,przejście nie prowadzi do nikąd”.

$\mathrm{Z}$ również nieznajdującą odbicia $\mathrm{w}$ kontekście oryginalnym, lecz celową stylizacją biblijną mamy z kolei do czynienia w innym fragmencie: „Jeśli nie pojmiemy opuszczenia i trwogi, męki i nocy agonii, będziemy jeno niewierną podobizną, źle ociosanym kamieniem odrzuconym przez budujących, który nie znajdzie miejsca w gmachu i nie posłuży niczemu” (Btędne cienie, 14$)<$ „Si nous n'embrassons pas l'abandon et l'angoisse, la passion, la nuit de l'agonie, nous ne sommes que des images infidèles, des pierres de rebut mal taillées qui ne peuvent plus entrer dans l'édifice et qu'on ne peut assortit à rien" (Les ombres errantes, 21). Umieszczony w miejscu francuskich „zwykłych” źle ociosanych i odrzuconych pierres 'skał' - polski kamień odrzucony przez budujacych budzi jasne skojarzenia z wyrażeniem kamień węgielny (jako ciąg dalszy cytatu z wersetu 22 Psalmu 118), które - jak podkreśla Stanisław Koziara - „należy do najbardziej utrwalonych frazeologizmów biblijnych w języku polskim" "15. Otwierają się w ten sposób dodatkowe ścieżki skojarzeń i możliwości interpretacyjne całego tekstu.

Powracając jeszcze na chwilę do kwestii defrazeologizacji: z pewnością gry „defrazeologizacyjne” bywają niebezpieczne, lecz poniżej podam tylko przykład pozytywny wybrnięcia z sytuacji zagrożenia błędem, pochodzący z powitalnego zwrotu do jednego z bohaterów: „Mów, co ci leży na sercu, Naderze!” (Skała Taniosa, 97) < „Vide ton sac, Nader” (Le Rocher de Tanios, 91) [opróżnij twój worek, Naderze]. W tym wypadku polski frazeologizm coś komuś leży na sercu jest wynikiem doskonałej interpretacji szerszego kontekstu i potwierdza dużą kompetencję językowo-kulturową autora przekładu, który uniknął błędu defrazeologizacji i dosłownego przetłumaczenia frazy „vide ton sac” jako „opróżnij twój worek”; takie zdarzają się najlepszym, o czym pisze Leon Zaręba w jednym z artykułów na temat kompetencji tłumacza, ilustrując ten mechanizm m.in. tytułowym przykładem entre chien et loup [między psem a wilkiem] 'o zmroku'l6.

15 S. Koziara, Frazeologia biblijna w języku polskim, Kraków 2001, s. 86.

${ }^{16}$ L. Zaręba, "Entre chien et loup » ou quelques réflexions sur la compétence du traducteur, w: Szkice z frazeologii porównawczej francusko-polskiej i polsko-francuskiej (Esquisses de phraséologie comparative franco-polonaise et polono-française), Kraków 2004, s. 209. 
Beata Jezierska

\section{The problem of phraseological units in literary translations from French into Polish (based on selected examples)}

The aim of this article is to present a part of the research results regarding the functioning of phraseological units (i.e. their canonical and innovative forms) in the Polish texts of contemporary prose translated from French. Consequently, there has been created a classification covering various types of relations occurring in given contexts between Polish phraseological units used by translators and the source texts. The practice shows that a translator decides from time to time to interpose a phraseological unit in a given context of the final text, even if there is no any kind of fixed expression in the original. Therefore, it is worth trying to find an answer to a question about translation decisions in this matter.

KEYWORDs: phraseologisms, canonical form, phraseological innovations, literary translation, translation relationship, translation equivalent.

mgr Beata Jezierska - doktorantka w Zakładzie Frazeologii i Kultury Języka Polskiego Instytutu Filologii Polskiej UAM; prowadzi zajęcia z kultury języka polskiego na studiach polonistycznych pierwszego stopnia. Interesuje się leksykologią, leksykografią, frazeologią i sztuką przekładu. Przygotowuje pracę doktorską dotyczącą frazeologizmów w polskich przekładach współczesnej prozy francuskiej. 